\title{
Plasma prolactin concentrations during the oestrous cycle of sows
}

\author{
Luiza Dusza and Halina Krzymowska \\ Institute of Animal Physiology and Biochemistry, Academy of Agriculture and Technology, \\ 10-718 Olsztyn, Poland
}

\begin{abstract}
Summary. Plasma prolactin levels were measured in 7 sows during the oestrous cycle after the 1st farrow. Blood samples were taken 4 times during the day $(07: 00,11: 00$, 14:00 and 19:00 h). The prolactin concentration was determined by a double-antibody radioimmunoassay method. There was an increase in plasma prolactin at the second oestrus after weaning, with a peak of prolactin 4 days before oestrus, regardless of the length of the cycle.
\end{abstract}

\section{Introduction}

Day, Anderson, Hazel \& Melampy (1959) and Threlfall, Martin, Dale, Anderson \& Kraese (1972) measured pituitary prolactin throughout the oestrous cycle of sows by means of the intradermal pigeon crop gland technique. Day et al. (1959) found that the amount of hormone increased until oestrus, and then dropped to a nadir, while Threlfall et al. (1972) reported the lowest values immediately after ovulation and highest in animals in the luteal phase of the cycle. Using a double-antibody radioimmunoassay, Threlfall, Dale \& Martin (1974) determined plasma and pituitary prolactin concentrations in sows during various phases of reproduction. The hypophysis of prepubertal virgin gilts contained more prolactin than did any of the other groups of sows. The amount of hypophysial prolactin decreased as the size and activity of mammary gland increased. Significant differences in circulating prolactin were not observed in virgin gilts, sows at mid-gestation, and sows at the 112th day of gestation. The effect of nursing on the quantities of prolactin in the serum and pituitary was also demonstrated. We have not found any papers concerning plasma levels of prolactin during the oestrous cycle in sows. In the present study, therefore, plasma prolactin concentrations were measured during the oestrous cycle.

\section{Materials and Methods}

The investigation were carried out on 7 sows of the Polish Large White breed weighing about 150 $\mathrm{kg}$ after the 1st farrow. The first day of oestrus after weaning of the young was designated as Day 0 of the oestrous cycle. Oestrus was detected by running the sows with the boar. The sows were kept in the conditions of an industrial pig farm. The blood samples were withdrawn daily at 07:00, 11:00, 14:00 and 19:00 h from a cannula inserted into the jugular vein (see Kotwica, Krzymowski \& Debek, 1978). The heparinized samples were centrifuged and the plasma was stored at $-20^{\circ} \mathrm{C}$ until assay.

\section{Prolactin assay}

Prolactin concentration was estimated by a double-antibody radioimmunoassay method as described by Schams \& Karg (1969) for bovine prolactin. The porcine prolactin preparation 
KK-2 (purified by K. Kochman) with an activity of $30 \mathrm{i.u} . / \mathrm{mg}$ was used as the antigen, standard and for iodination. The purification procedure was essentially as described by $\mathrm{Li}(1976)$ but a purification step by DEAE-cellulose chromatography was introduced as described by Kochman \& Kochman (1977). This preparation of porcine prolactin was free of porcine GH, LH and FSH, as tested by polyacrylamide gel electrophoresis. Rabbit anti-porcine prolactin was used at a final dilution of $1: 40000$. The antibody used showed no cross-reaction with purified porcine GH (NIH-P-526B), porcine LH and porcine FSH (produced in our laboratory). Anti-rabbit gammaglobulin, prepared in sheep, was used at a dilution of $1: 10$. Porcine prolactin $(5 \mu \mathrm{g})$ was iodinated by a modification of the method of Bryant \& Greenwood (1968), using $1.2 \mathrm{mCi}{ }^{125}$ (Institute of Nuclear Research, Swierk, Poland) and $17 \mu \mathrm{g}$ chloramine T. Iodination was at $4^{\circ} \mathrm{C}$ and was stopped after $20 \mathrm{sec}$ by adding $60 \mu \mathrm{g}$ sodium metabisulphite. The labelled porcine prolactin was further purified through a column of Sephadex G-75 $(1 \times 40 \mathrm{~cm})$, equilibrated with $0.07 \mathrm{M}$ veronal buffer, $\mathrm{pH} 8 \cdot 6$. The standard curves of the $\mathrm{KK}-2$ porcine prolactin preparation were compared with the curve of porcine prolactin SP-162-C kindly given to us by Dr L. E. Reichert. No differences were observed. The results of determinations with various dilutions of the plasma showed parallel curves. The regression line was $y=-0 \cdot 11+0.933 x$ and the correlation was 0.98 . The recovery after addition of various amounts of prolactin to the plasma was $109.74 \pm$ 15.00 (s.d.)\% $(n=23)$. The sensitivity of the assay was $0.15 \mathrm{ng}$ prolactin $/ \mathrm{ml}$. The coefficient of variation was $<3 \%$ within assays and $<10 \%$ between assays.

\section{Results}

Text-figure 1 shows plasma levels of prolactin in sows with an oestrous cycle of 21 days. The basal level of prolactin oscillated from 3 to $20 \mathrm{ng} / \mathrm{ml}$ in 4 sows but 1 sow had a basal level of only 1-3 ng/ml. At the first oestrus after weaning (I) the prolactin concentration was slightly increased, but at the second oestrus after weaning (II) a sharp elevation of prolactin occurred.

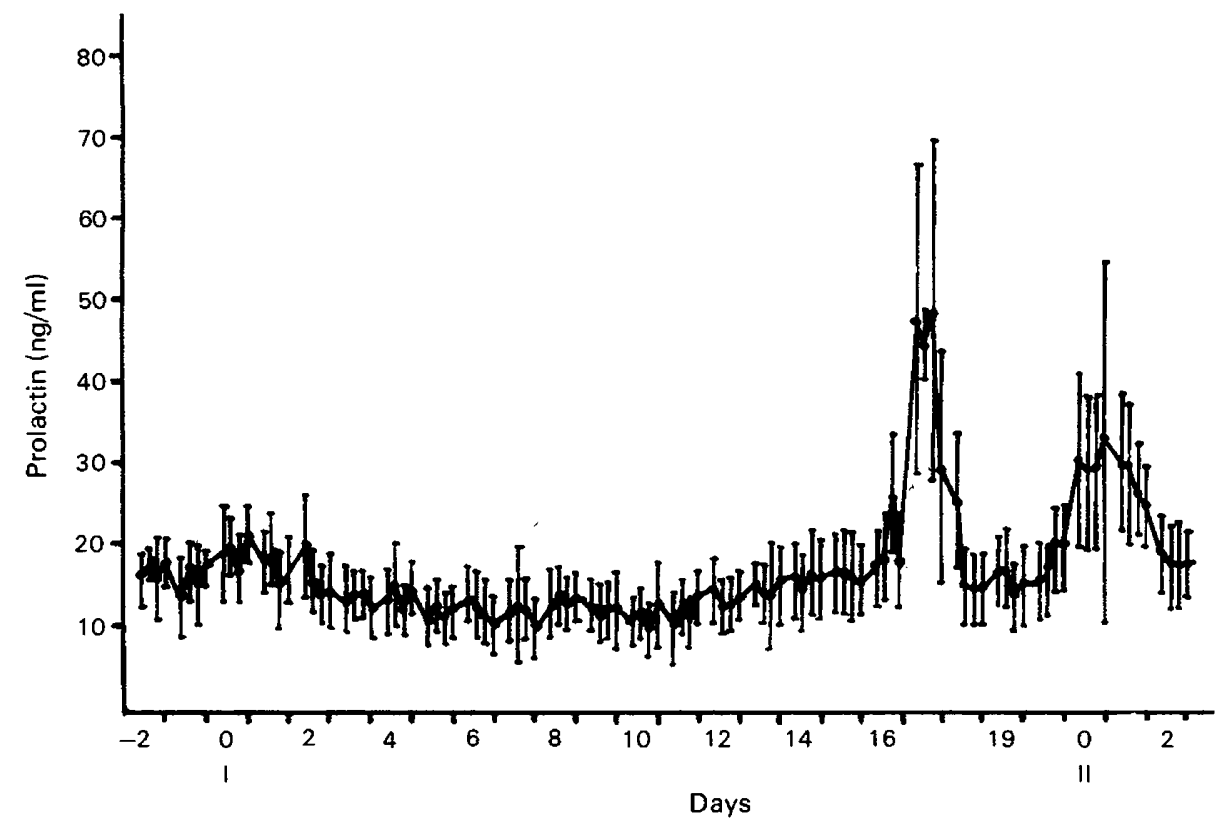

Text-fig. 1. Mean \pm s.e.m. prolactin concentrations in the blood plasma of 5 sows with a 21-day oestrous cycle. $I=$ first oestrus after weaning; II = second oestrus after weaning. 


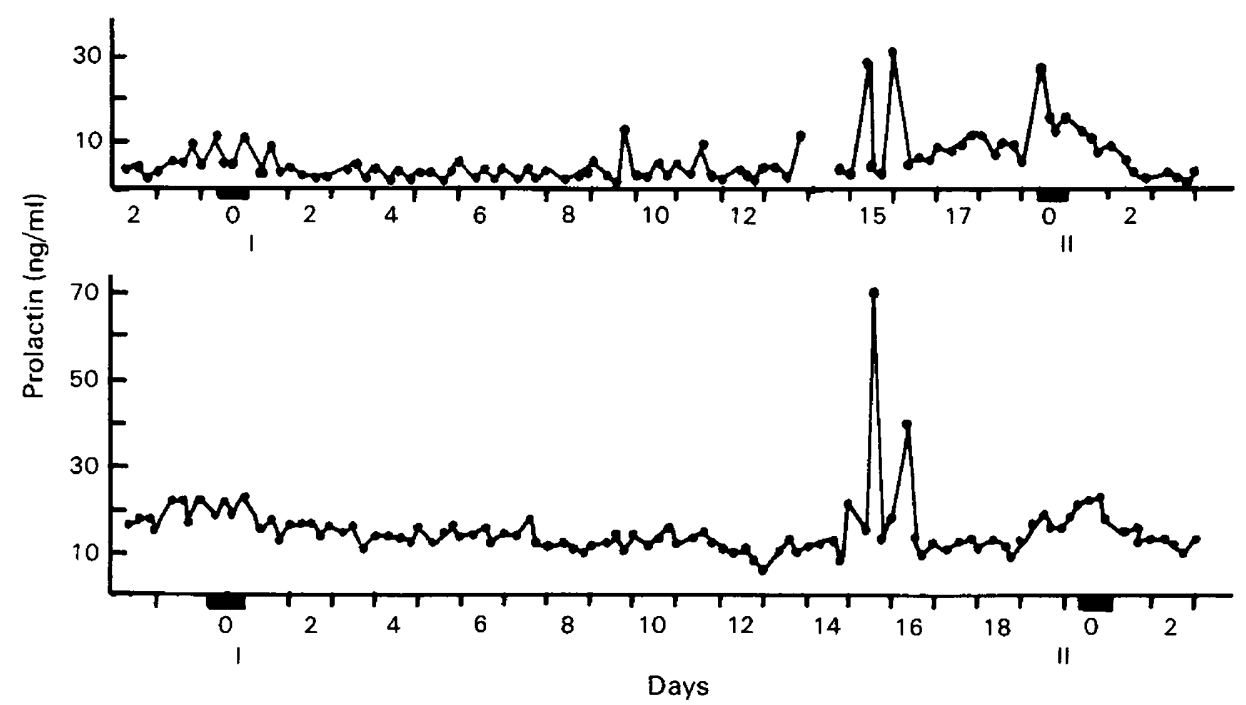

Text-fig. 2. Prolactin concentrations in the blood plasma of 2 sows with an oestrous cycle of $<20$ days. I = first oestrus after weaning; II = second oestrous after weaning.

The highest concentration of plasma prolactin was observed at the 17 th day of the oestrous cycle and was regularly and repeatedly observed in several sows. In 2 sows with a shorter oestrous cycle the peak of prolactin occurred earlier, at the 15th day of the cycle (Text-fig. 2).

\section{Discussion}

The timing of the plasma prolactin changes in the oestrous cycle was regular, the differences being mainly of the actual concentrations reached in the animals. The highest prolactin level was observed at the 4th day before oestrus and was probably caused by oestrogens. Signs of oestrus, i.e. vulval enlargement and lordosis, were clearly seen during the second oestrus after weaning.

The interrelationship of oestrogens and prolactin has been described by many authors (Robyn et al., 1973; Yokoyama, Tomagane \& Ota, 1974; Meites, 1977). The peak of prolactin which has been observed at the 1st day of the cycle is inversely associated with the level of progesterone. The prolactin peak occurs before the LH peak (unpublished results from our laboratory). The work of Rolland \& Hammond (1975) and Rolland, Gunsalus \& Hammond (1976) has shown that there are some receptors which bind prolactin in the ovary of sows. Porcine granulosa cells from small follicles $(<3 \mathrm{~mm})$ have more specific binding sites for prolactin than do cells from medium-sized $(3-7 \mathrm{~mm})$, or large $(>7 \mathrm{~mm})$ follicles. The corpus luteum also has more specific binding of prolactin than does the corpus haemorrhagicum or corpus albicans. On the basis of our results, as well as those of Rolland et al. (1976), it can be concluded that prolactin may play a role in the regulation of the oestrous cycle of sows.

This work was supported by the Institute of Pathology and Therapy of Animals, Agriculture Academy, Wrocław, as part of the Research Project of the Ministry of higher Education, Science and Technology (MR-II-10).

\section{References}

Bryant, G.D. \& Greenwood, F.C. (1968) Radioimmunoassay for ovine, caprine and bovine prolactin in plasma and tissue extracts. Biochem. J. 108, 831840.
Day, B.N., Anderson, L.L., Hazel, L.N. \& Melampy, R.M. (1959) Gonadotrophic and lactogenic hormone potencies of gilt pituitaries during the estrous cycle and pregnancy. J. Anim. Sci. 18, 675-682. 
Kochman, H. \& Kochman, K. (1977) Purification of ovine and bovine prolactins on DEAE-cellulose chromatography and preparative polyacrylamide gel electrophoresis. Bull. Acad. Sci. Polon. ser. Sci. Biol. 25, 67-70.

Kotwica, J., Krzymowski, T. \& Debek, J. (1978) Kaniulizowanie naczyń żylnych do badań endokrynologicznych. Medycyna Wet. 34, 118-120.

Li, C.H. (1976) Studies on pituitary lactogenic hormone. The primary structure of the porcine hormone. Int. J. Peptide Protein Res. 8, 205-224.

Meites, J. (1977) Evaluation of research on control of prolactin secretion. In Comparative Endocrinology of Prolactin, pp. 135-152. Eds H.-D. Dellmann, J. A. Johnson \& D. M. Klachko. Plenum Press, New York.

Robyn, C., Delvoye, P., Nokin, J., Vekemans, M., Badawi, M., Perez-Lopez, F.R. \& L'Hermite, M. (1973) Prolactin and human reproduction. In Human Prolactin, pp. 167-188. Eds J. L. Pasteels \& C. Robyn. Excerpta Medica, Amsterdam.
Rolland, R. \& Hammond, J.M. (1975) Demonstration of a specific receptor for prolactin in porcine granulosa cells. Endocrine Res. Commun. 2, 281-298.

Rolland, R., Gunsalus, G.L. \& Hammond, J.M. (1976) Demonstration of specific binding of prolactin by porcine corpora lutea. Endocrinology 98, 10831091.

Schams, D. \& Karg, G.S. (1969) Radioimmunologishe Bestimmung von Prolaktin in Blutserum von Rind. Milchwissenchaft 24, 263-265.

Threlfall, W.R., Martin, C.E., Dale, H.E., Anderson, R.R. \& Kraese, G.F. (1972) Pituitary prolactin and the oestrous cycle of sows. J. Reprod. Fert. 31, 201-204.

Threlfall, W.R., Dale, H.E. \& Martin, Ch.E. (1974) Porcine blood and hypophyseal prolactin values. $A m$. J. vet. Res. 35, 1491-1493.

Yokoyama, A., Tomogane, H. \& Ota, K. (1974) Regulation of the surge of prolactin at proestrus in cycling rats. In Biological Rhythms in Neuroendocrine Activity, pp. 187-196. Ed. M. Kawakami. Igaku shoin Ltd, Tokyo.

Received 26 April 1979 